\title{
Blaming Beauty for the Beast: A Jungian Explanation for the Persistence of Patriarchal Patterns
}

\author{
Sherri DioGuardi ${ }^{1 *}$, Ashley Wellman ${ }^{2}$, Frances P. Reddington ${ }^{1}$ \\ 1 University of Central Missouri, USA \\ ${ }^{2}$ Texas Christian University, USA
}

*Corresponding Author: dioguardi@ucmo.edu

Citation: DioGuardi, S., Wellman, A. and Reddington, F. P. (2019). Blaming Beauty for the Beast: A Jungian Explanation for the Persistence of Patriarchal Patterns, Journal of Cultural Analysis and Social Change, 4(1), 03. https://doi.org/10.20897/jcasc/5846

Published: July 19, 2019

\begin{abstract}
Rape was a prominent theme in Greek mythology and has recently re-emerged in the media spotlight due to the \#MeToo and \#TimesUp movements as well as celebrity-involved cases of sexual assault and sexual harassment (i.e., Bill Cosby and Harvey Weinstein). The current paper examines three ancient Greek myths involving rapes committed by gods. A qualitative content analysis was done to compare these myths to modern day sexual assaults. Latent content results were analyzed and framed within the context of Jungian theory. Prior research has placed rape and other sexual assaults within a patriarchal framework, presuming strategic male hegemony. Archetype theory offers an alternative, and more benign, explanation for the prevalence of rape myths, the persistence of gender power differentials, and for the perpetuation of ancient stereotypes. Analysis of study findings within a Jungian framework suggests a possible solution for these persistent problems within society, one worthy of empirical investigation.
\end{abstract}

Keywords: Carl G. Jung, archetype theory, rape, sexual assault, patriarchy, misogyny, feminism, myths, Greek mythology, stereotypes

\section{INTRODUCTION}

Recently, there has been heightened public awareness of sexual assault and harassment as a result of celebrities (i.e., Harvey Weinstein, Bill Cosby, and Larry Nassar) dominating broadcast news and social media. The latest \#MeToo movement has shed light on the far-reaching impact of sexual assault and the emotional and physical effects that follow. Despite the recent focus on the issue of sexual abuse, few people realize that current rape myths and the accompanying negative perceptions of rape victims have long-standing historical roots. For instance, Medusa, the Greek monster who had venomous snakes for hair, was once a beautiful maiden. After being raped by Poseidon, she was denounced and demonized for her victimization. Other mythological women endured similar fates. This paper draws parallels between three mythological stories and three modern-day accounts of criminal sexual behaviour, and then offers the Jungian concept of archetypes to explain those parallels.

\section{GREEK MYTHOLOGY \& ARCHETYPES}

Myths have been referred to as society's sacred stories (Lule, 2001) because they persist generationally as a result of their evocative nature. Myths are ideological rather than factual (Dowden, 1995). While ideology has been defined as a belief or conviction (Livingstone, 2008), in reality, ideology is the force that empowers specific beliefs 
or convictions. Sometimes, as with certain Greek myths, that force is brutal, but that is primarily because almost everything is amplified or bigger than life in Greek myths. Also, raw, undiluted emotions and exaggerated traits allow myths (or exemplars) to be more easily visualized and remembered (Gibson and Zillmann, 1994; Morgan and Dennehy, 1997), and it is those types of archetypal characteristics that enable myths to continue to resonate in the modern world.

It was C. G. Jung, renowned Twentieth Century Swiss psychiatrist and founder of analytical psychology, who used the term 'archetype' to represent a 'primordial image' (Jung, 1968, p. 57). Jung considered archetypes to be akin to the embodiment of primitive emotions imbedded within a 'collective unconscious' (Stevens, 1994, p. 47). For Jung (1968), the persistent power of archetypes could not be overstated: "[A]rchetypes create myths, religions, and philosophies that influence and characterize whole nations and epochs of histories" (p. 68). By looking back at Greek myths and the archetypes contained within them, it may be possible to trace the germination of gender ideology in the modern world to better understand the presence of rape then and now and to also possibly explain societal reactions to sexual assault.

\section{WOMEN \& RAPE IN GREEK MYTHOLOGY}

Greek myths were early ancestors' attempts to understand relationships and explain origination. At first, according to myth, only the male human was created by Prometheus, a Titan god, and it was not until later that the first mortal woman was created as the way to punish man for fire being stolen from the sun. Upon instructions from Zeus, the king of the gods, Pandora was created as a torment to man, and she was described as kalon kakon, or 'beautiful evil' (Zeitlin, 1995, p. 59). While many people today may not know that Pandora was the first female creation in Greek mythology, they will likely recognize the phrase 'Pandora's box,' and know that Pandora was blamed for bringing 'death, woe, and evil into the world' (Zeitlin, 1995, p. 49).

One of the vilest accounts of rape and murder in Greek mythology is the story of Princess Philomela being raped and mutilated by her brother-in-law, King Tereus of Thrace. Neither were gods, but both were royalty. After the sexual assault, Tereus commanded Philomela to keep silent about the rape; when she refused, he cut out her tongue. Even though she no longer had a voice, Philomela created a tapestry upon which she had written within the weavings the story of her sexual assault, and she sent that to her sister, Procne, who was the wife of Tereus (the rapist). After learning what her husband had done to her sister, Procne was enraged and killed her own son (who was fathered by Tereus) in revenge. Procne then cooked and served those remains as a meal to her husband. After Tereus finished eating, Procne brought out their son's severed head so that Tereus would know the horror of cannibalizing his own son (Encyclopaedia Britannica, 2018a).

Despite this myth being rewritten very concisely in the preceding paragraph, the violence remains vivid. This illustrates how viscerally potent the images contained in myths are, even when retold thousands of years later. That is what Jung (1968, p. 87) meant when he described the quality of 'numinosity' being present with archetypes or emotion-packed symbols.

\section{WOMEN \& RAPE IN MODERN SOCIETY}

In modern United States history, rape was viewed as a crime against property, and the husband or father would be recognized as the victim (Burgess-Jackson, 1996). Rape, therefore, was viewed as lessening the value of the female property, and it required financial recompense paid to her male 'owner' (Burgess-Jackson, 1996). While women are no longer legally viewed as property in America, the differential power that men hold over women remains problematic. Patriarchal and misogynous attitudes continue to be related to the commission, and acceptance, of rape and other sexual assaults (Murnen et al., 2002).

Feminists have reframed rape as a crime motivated by control, anger and power, designed to strip dignity from its victims. Brownmiller (1975) specifically challenged rape as a form of sex and instead defined rape as an expression of masculinity that endeavors to keep women oppressed through fear. This new perspective reframed rape as a political act as much as an individual crime. Radical feminism asserts men, not women, have maintained control over the female body for reproductive and sexual purposes (Whisnant, 2007). Men may use violence or threats of violence as forms of power to control their female victims. Rape-prone civilizations - such as the Kenyan tribe of Kikuyu, the Arunta which is an Aboriginal Australian population, and the Mundurucu from Brazil - use rape as threat, punishment, or even as a ceremonial act (Sanday, 1981). There are still 12 countries with 'MarryYour-Rapist Laws' which allow a rapist to escape prosecution if he agrees to marry his victim; and the coerced marriage is often viewed by the victim as her only way to regain honor (Raphelson, 2017).

Feminists also argue that the domination of the sexual experience by men causes women to lack sexual freedom and to unconsciously fill the role of submissive, blurring the lines between consensual sex and rape (Whisnant, 
2007). While not always legally rape, men may utilize power and coercion to lure women into sexual engagement. Patriarchal views which oppress women are furthered by the transmission of misogynistic comments, jokes, and fantasies (Ford and Ferguson, 2004). Common misconceptions of sexual assault, its victims, and the perpetrators articulate similarly misguided and detrimental ideas. Burt (1980) termed many of these false beliefs broadly as 'rape myths' (p. 217).

"Rape myths are attitudes and generally false beliefs about rape that are widely and persistently held" (Lonsway and Fitzgerald, 1994, p. 133). These myths are held both by individuals in society and by the institutions entrenched within society (Edwards et al., 2011). While there are many rape myths, this article focuses on the myths that remove blame from the male offender by excusing his behaviour and transferring blame to the victim due to her voluntary alcohol consumption, physical appeal, choice of clothing, or promiscuous past (Burt, 1980; Lonsway and Fitzgerald, 1994; Suarez and Gadalla, 2010). Rape myths harm society by trivializing rape and all forms of sexual assault and by discounting their long-term psychological effects (Iconis, 2008). Because rape myths are attributed to a patriarchal society and patriarchy is defined as a political system in which males dominate and perpetually maintain power over laws and policy (Lerner, 1986), the presumption has primarily been that the persistence of the control and oppression of women has been conscious and strategic; that the domination has been deliberately driven. The explanation presented in this article presumes a much less malignant motive, and that is a theory of archetypes (Jung, 1968). This paper proposes that the persistence of patriarchal attitudes and behaviors in society may have less to do with conscious intent and much more to do with unconscious content (archetypes). The reason this distinction is relevant and important is not to excuse sexual assaults or even minimize the harm caused by rape myths. Instead, this article offers a new avenue to explore, one which has the potential to provide a way out of the 'sexist stalemate' position that patriarchy has appeared to place upon society. Current theories tend to make males and females antagonistic to each other, and antagonism is never conducive for creating collaborative solutions.

\section{THE THEORY OF ARCHETYPES}

Jung (1968) was convinced that archetypes represent evolutionary pre-programming or patterns that pre-exist in everyone, akin to an imprint created from an action repeatedly occurring in early history and becoming a pattern of default survival behavior.

[Archetypes] are, in a sense, the deposits of all our ancestral experiences themselves... all those factors, therefore, that were essential to our near and remote ancestors will also be essential to us, for they are embedded in the inherited organ system (Jung, 1972, p. 717).

Jung (1968) considered archetypes to be natural and neutral in value but recognized their potential for stimulating reactive, non-reflective responses that might be perceived as being prejudicial. Archetypes, which have been called residue from ancient memories, are an unconscious link to the collective mind of our earliest ancestors (Jung, 1968).

Modern man is in fact a curious mixture of characteristics acquired over the long ages of his mental development. This mixed-up being is the man and his symbols that we have to deal with, and we must scrutinize his mental products very carefully indeed. Skepticism and scientific convictions exist in him side by side with old-fashioned prejudices, outdated habits of thought and feeling, obstinate misinterpretations, and blind ignorance (Jung, 1968, p. 86).

Jung (1968) was convinced that the reason people dream so vividly in archetype forms is because the unconscious is attempting to bring those ancestral imprints into conscious awareness for acknowledgement and insight.

The symbol-producing function of our dreams is thus an attempt to bring the original mind of man into "advanced" or differentiated consciousness, where it has never been before and where, therefore, it has never been subjected to critical self-reflection. For, in ages long past, that original mind was the whole of man's personality. As he developed consciousness, so his conscious mind lost contact with some of that primitive psychic energy (Jung, 1968, p. 88).

Some scholars have compared Jungian philosophy with that of Friedrich Nietzsche (Huskinson, 2004) because Nietzsche "suggested a plan for 'becoming what one is' throughout the cultivation of instincts and various cognitive faculties, a plan that requires constant struggle with one's psychological and intellectual inheritances" (Wilkerson, 2019, para. 3). Nietzsche termed the fundamental driving force within all life forms as the will to power. Nietzsche's will to power may be interpreted as the battle between the rational mind and primordial instinctive drives; 
such struggle could be overcome through reaching an equilibrium between the two or an integration, which was Nietzsche's concept of Übermensch or whole self (Huskinson, 2004). This aligns with Jung's belief that human beings will only reach their highest potential when they stop denying or repressing primordial instincts and, instead, work diligently to bring them into conscious awareness and under cognitive control.

Bringing personal archetypes out of the shadows (the unconscious) and into the light (the conscious) is also how analytical therapists believe a person becomes whole (Jung, 1968). In society, the same principle applies. It can only be after archetypes are brought into cultural awareness that people will stop being so susceptible to forces that, for centuries, have resided within the collective unconscious (Jung, 1968).

Analyzing language may also illuminate archetypes (or imbedded bias) because words can be viewed as both expressions of symbols and as stand-alone symbols. "[A] symbol is a term, a name, or even a picture that may be familiar in daily life, yet that possesses specific connotations in addition to its conventional obvious meaning" (Jung, 1978, p. 3). For example, when referring to a subject as an invalid, the speaker may not be consciously aware of the etymology of the word because of the different pronunciation, but the subject's subconscious will instinctively sense the derogation from literally being dismissed as in-valid. In critical language studies, there is a term called naturalization, which is when ideological language becomes so mainstream that it appears to be free of ideology and is generally accepted as unbiased (Fairclough, 2001). For instance, mass media and even judicial reporting may use evocative words to describe sexual assault; i.e., referring to women's underwear as panties or using the term fondling for a forcible touching (Judicial Language Project, n.d.); and these titillating terms may slip past conscious awareness despite connoting a decreased degree of crime culpability. Over time, they may become naturalized, which hides the harm and reinforces archetypal stereotypes and rape myths, both individually and collectively across society.

While the concepts of archetypes and a collective unconscious are foundational principles in analytical psychology, there has been little attempt to empirically test these concepts outside of that discipline (SotirovaKohli et al., 2013). Part of the problem is that Jung never formulated his theory in a way that would allow easy testing (Stevens, 1994). Jung believed the reason his books were not well read or understood was due to the difficulty of explaining with words a phenomenon that pre-existed language; for him, the archetype was a 'hypothetical and irrepresentable model' (Jung, 1969, p. 5). Because Jung was trained as a medical doctor and was up-to-date in scientific knowledge, he saw a similarity between archetypes and the 'pattern of behavior' (Grillner, 2006, p. 751) phenomenon from biology, which allowed him to state with confidence: "Not the criticism of individual contemporaries will decide the truth or falsity of these discoveries, but future generations" (Jung, 1966, p. 201).

Since Jung's passing in 1961, a variety of different disciplines have independently come up with their own version of the archetype (Stevens, 1994). Neurobiologists call a similar concept 'instinctual psychological processes' (Goodwin, 2012, p. 11). Ethologists or behavioral biologists have identified innate releasing mechanisms (IRMs) which are patterns of behavior that are activated by sign stimuli in the environment (Stevens, 1994). In addition, the triune brain (MacLean, 1990), a popular but overly simplified model, was developed that fits in well with Jung's theory of archetypes. The triune brain model shows the brain as being comprised of three evolutionary layers with the earliest layer labeled as the reptilian brain; the next evolutionary brain level as the limbic brain system or emotional brain; and the last layer as the new mammalian brain. Only the latest brain level is hypothesized to be involved with higher order reasoning, and that is the area of the brain that is thought to be most plastic or capable of continuous adaptation; in contrast, the reptilian brain would be the least likely to change, would be the seat of survival instincts, and would be the most likely location of the archetypes (Goodwin, 2012). "Archetypes emerges as a nonmystical but profound representation of the deep organizing unconscious, which cognitive science has finally helped us to understand as a mechanism" (Fonagy, 2003, p. xv).

While word association (WA) tests are widely used today (Fitzpatrick et al., 2015), it is rarely acknowledged that Jung was an early pioneer of that methodology. Jung used WA tests to provide empirical support for the existence of a universal depository of archetypes (Stevens, 1994). Results of recent studies utilizing word association and word matching tests support the idea that the unconscious, rather than conscious, retains knowledge of archetypal symbols, even cross-culturally (Huston et al., 1999; Brown and Hannigan, 2006). While not a direct test of the theory of archetypes, Roesler (2013) reviewed empirical studies that evaluated the effectiveness of Jungian psychotherapy for patients and found it was effective in (1) reducing symptoms, (2) decreasing healthcare claims, and (3) successfully concluding most treatment after an average of 90 sessions.

Critics of Jung's theory of archetypes argue that human migration and cultural diffusion sufficiently explain the universality of symbols across cultures (Stevens, 1994). While it is intriguing that other disciplines have independently come up with concepts similar to archetypes and a collective unconscious, more empirical studies are needed. Despite the small body of literature, however, the theory has instinctive appeal and provides an explanation for why - despite changing laws, a progressive society, and the passage of time since the creation of 
the Greek myths - parallels still exist between those mythical accounts of rapes and sexual assaults that occur thousands of years later.

\section{METHODOLOGY}

\section{Research Design}

The current study is guided by the following research question: To what extent, if any, do the presentations of rape in Greek mythology and the facts of three modern day sexual assault cases parallel each other? A qualitative content analysis compared these mythological rapes to three media accounts. While plots were purposely chosen that contained rape portrayals in the Greek myths, when utilizing content analysis, 'how the story is told and how characters are portrayed are often more telling than specific plot points' (Kort-Butler, 2016, p. 5). Here, a latent analysis was conducted because, instead of looking at specific words (which undoubtedly changed through repetitive retelling of the mythological stories), the objective was to uncover the overall meaning being conveyed, as that likely remained intact over time.

The criteria for choosing a modern case to analyze was (1) it needed to be a sensationalized case that (2) involved a male athlete or celebrity, i.e., someone who could be the modern equivalent for the mythological Greek god, (3) in which there had been a lawful conviction in the criminal justice system. In addition, (4) there needed to be sufficient coverage of the case so that facts could be accessed as well as (5) reliable information on how the public reacted. Lastly, (6) enough time had to have passed so that follow-up information could also be attained. The three modern cases selected were State of Indiana v. Michael G. Tyson, People (of the State of California) v. Roman Raymond Polanski, and People (of the State of California) v. Brock. Turner.

\section{Qualitative Content Analysis}

\section{Mythological account: Medusa \& Poseiden}

Legend has it that the world was divided into three parts after the War of the Titans, and three supreme brothers - Zeus, Poseidon and Hades - drew straws to find out which one-third of the world would become their kingdom: the sky, the sea, or the underworld. Poseidon became the sea god. According to Ovid, around $8 \mathrm{AD}$, in Metamorphoses, Medusa was born human and quite beautiful. "Every man who saw her face and her gorgeous, silken hair immediately asked for her hand in marriage - all but one" (Saldarriaga, 2015, p. 8). And that one was not a man, but a god. While the virginal Medusa reposed in Athena's temple, Poseidon raped her, an act which also defiled Athena's temple. Athena blamed Medusa for the defilement of her temple, and 'also chose to punish Medusa for her part in the whole affair - she cursed Medusa's beauty' (Saldarriaga, 2015, p. 8). She punished Medusa by turning her locks of hair into serpents and causing her face to be so horrible that merely glancing at it would instantly transform the observer to stone. Medusa was forced to go into exile, and she was eventually beheaded (Freeman, 2013).

\section{Modern Account: Desiree Washington \& Mike Tyson}

Present day parallels were drawn between this Greek myth and the case involving Desiree Washington and convicted rapist, Mike Tyson. Mike Tyson, known as 'Iron Mike,' had been the youngest heavyweight boxing champion of the world. When he was 26 years old, after having recently lost the heavyweight boxing title, Tyson was persuaded to lend his celebrity name and presence to the Miss Black America pageant held in Indianapolis on July 19, 1991. While present at the pageant festivities, Tyson saw Desiree Washington, a beautiful, 18-year-old woman; Desiree had recently graduated from high school and was a part-time Sunday school teacher (Corliss, 2001) who aspired to go into law and politics; she was outgoing and enjoyed being part of the beauty pageant events (Walters, 1992). After agreeing to go out with Tyson on a late-night date, Desiree went with him to his hotel room, where a jury later found that she was raped by him. Tyson was sentenced to a six-year prison term, but he was subsequently released after serving only three years. One of the prosecutors in the case gave the following statement about Desiree Washington: "She is imprisoned herself emotionally for the rest of her life...There are so many competing fears and concerns. This child has no sense of happiness or elation. It'll take months just to get back to normal and that's what she's trying to do" (Shipp, 1992, p. 23). One of Desiree's concerns was related to the vast number of Tyson fans who were blaming her and supporting him. At least one study showed that $60 \%$ of television station viewers did not agree with the jury's verdict of guilt for Tyson (Corliss, 2001). Such unsympathetic and hard-hearted response to Desiree by a slight majority of the public might be seen as the manifestation of the metaphoric 'turning to stone' by those who viewed Medusa.

Desiree Washington disappeared from public view after giving an interview to Barbara Walters within days after Tyson's conviction. A Newsday article (Gelman, 1995) reported on Desiree's life still being shattered nearly four years after the rape occurred. This portrayal was in sharp contrast to Tyson, who was picked up by a chauffeur- 
driven limousine on the day he was released from prison and announced to the press that he had just signed a contract with MGM Grand in Las Vegas which would potentially mean earnings of up to $\$ 50$ million for his first post-prison professional fight. Before the rape, Desiree was 'always at the center of attention' (Gelman, 1995, p. 14), but after the rape, she shunned the spotlight. Her family broke up soon after the sentencing, and the happy home in which Desiree grew up had to be sold so that Desiree's father and younger sister could escape constant harassment by Tyson supporters (Gelman, 1995). This destruction of the family home parallels the defilement of Athena's temple.

In 2017, 26 years after the rape, the first 17 hits from a Google search of 'Desiree Washington' prominently display the name of Mike Tyson. Not only has Desiree Washington disappeared from the public eye (a virtual exile), but her once independent identity appears to have been obliterated because she no longer exists on-line at all except in relation to her rapist. While Tyson's international fame might explain his prominent online presence, it does not explain the complete absence of any updated online information about Desiree Washington individually. This obliteration represents Desiree's symbolic beheading by the Athena-like public.

\section{Mythological Account: Leda \& Zeus}

A well-known myth in the Middle Ages, the horror of the rape of Leda, was not really addressed until 1928 in the William Butler Yeats sonnet and in fact was even romanticized during the Italian Renaissance (Norfolk, 2010). Zeus, 'father and ruler of all the gods of Ancient Greece' (Norfolk, 2010, p. 5) and controller of lightning, saw the very young mortal maiden, Leda, by a lake and desired her. When Leda fled, Zeus 'transforms himself into the shape of a swan and proceeds to sneak up on Leda and rape her' (History of rape culture, n.d., p. 3). The following is the first stanza from a sonnet written by William Butler Yeats (1928) describing the violent act: "A sudden blow; the great wings beating still above the staggering girl, her thighs caressed by the dark webs, her nape caught in his bill. He holds her helpless breast upon his breast" (p. 33). In this sonnet, the act is 'an unambiguously brutal rape after which the victim is indifferently discarded' (Norfolk, 2010, p. 7).

\section{Modern Account: Samantha Geimer \& Roman Polanski}

Leda's assault is directly contrasted with the rape of Samantha Geimer. In 1977, Samantha was a 13-year-old child who was desired by wealthy, award-winning Hollywood director, Roman Polanski. In order to get Samantha to accompany him alone and unchaperoned, Polanski tricked both Samantha and her mother into believing that he was taking Samantha to model for a Vogue photo shoot. This was similar to Zeus disguising himself as a swan in order to trick Leda. Instead, of taking her to a photo shoot, Polanski took Samantha to a fellow celebrity's house where it is undisputed that she was drugged and sexually assaulted. Polanski pled guilty to unlawful sexual intercourse with a minor and expected to be sentenced to the 42 days in jail already served months earlier. The night before the sentencing hearing, however, Polanski learned that the judge was likely not going to agree to the plea deal negotiated by his defense attorney and the prosecutor, and so he fled America (Toobin, 2009). Polanski has maintained dual citizenship in France and Poland, and both countries have refused all requests to extradite him (Doezema, 2018; Kolanko and Cieply, 2015). In 2013, Polanski received the Lifetime Achievement Award at the Zurich Film Festival (Serisier, 2017). It was only last year that Polanski (along with Bill Cosby) was expelled from membership of the Academy of Motion Pictures Arts and Sciences (Melas and France, 2018). In Los Angeles County, an arrest warrant issued in 1978 remains outstanding for Polanski (Oehling and Cummins, 2017).

Despite no dispute over the facts - a 40-some year-old man drugging and sexually assaulting a 13-year-old girl - there was support from the public for Polanski being allowed to return to the United States, and legal petitions were filed, requesting all charges be dismissed (Toobin, 2009). The View co-host Whoopi Goldberg minimized the crime by stating on national television that 'it wasn't rape-rape' (Keegan, 2013, p. 2), which is similar to how Leda's mythological rape is sometimes seen as a seduction.

\section{Mythological Account: Aura \& Dionysus}

The rape of Aura by Dionysus, son of Zeus, is recounted in the epic poem Dionysiaca (Nonnus, 1940). Dionysus is also the god credited with granting King Midas the power to turn everything he touched into gold (Encyclopaedia Britannica, 2018b). Aura was a young and beautiful virgin huntress who offended the goddess Artemis, daughter of Zeus, by questioning her virginity. In retaliation, Artemis sought revenge by having Aura sexually assaulted by Dionysus, the god of wine (Spanoudakis, 2014). Dionysus saw Aura, desired her, and so deliberately got her drunk. Once she passed out, he raped her (Lightfoot, 2000). When Aura awakened, 'she saw with surprise her breasts bare of the modest bodice, the cleft of her thighs uncovered, her dress marked with the drops of wedlock that told of a maidenhood ravished...She was maddened by what she saw' (Nonnus, 2015, Book XLVIII, p. 652). In contrast, Dionysus became revered for bestowing the gift of wine to mankind, and for centuries he inspired a cult following (Cartwright, 2012). 


\section{Modern Account: Emily Doe \& Brock Turner}

Significant parallels are present when examining the case of Aura alongside the sexual assault of Emily Doe. Two witnesses came upon Brock Turner, a Stanford University student, sexually assaulting Emily Doe on campus grounds while she was unconscious. Turner claimed he received verbal consent before 'Emily' had passed out. The media made much of the fact that Turner was an aspiring Olympic swimmer, and in some accounts the assault was described almost as if it were merely a drunken indiscretion on Turner's part. Turner was convicted of three counts of felony sexual assault: (1) assault with intent to commit rape of an intoxicated or unconscious person, (2) penetrating an intoxicated person with a foreign object; and (3) penetrating an unconscious person with a foreign object (James, 2018). He was sentenced to six months in jail followed by three years of probation with the condition that he register as a sex offender and complete a treatment program. He was released in three months (Grinberg and Shoichet, 2016). Emily's real name was never made public, and her image was never broadcast. She did, however, give a victim-impact statement at the criminal court hearing which went viral on social media. In the statement, she addressed Turner directly, "You don't know me, but you've been inside me, and that's why we're here today" (Bever, 2016, p. 10). She described how she came to while on a gurney in a hallway and how, after a few hours of being poked and prodded by medical personnel and having all her scratches and abrasions photographed, she was finally allowed to shower. She stated how she felt as she looked down at her own body:

I stood there examining my body beneath the stream of water and decided, I don't want my body any more. I was terrified of it. I didn't know what had been in it, if it had been contaminated, who had touched it. I wanted to take off my body like a jacket and leave it at the hospital with everything else (Bever, 2016, p. 15).

Like Aura, she was maddened, as she told her attacker: "If you are hoping that one of my organs will implode from anger and I will die, I'm almost there. You are very close" (Bever, 2016, p. 46). She responded to some of the comments contained in the defendant's written statement that was proffered to the court, such as his assertions that he was establishing a program where he will go to high schools and colleges to 'speak out against the college campus drinking culture and the sexual promiscuity that goes along with that' because he wants to 'show people that one night of drinking can ruin a life.' Here was her response:

A life, one life, yours. You forgot about mine. Let me rephrase for you. I want to show people that one night of drinking can ruin two lives. You and me. You are the cause. I am the effect. You have dragged me through this hell with you, dipped me back into that night again and again. You knocked down both our towers. I collapsed at the same time you did. If you think I was spared, came out unscathed, that today I ride off into sunset while you suffer the greatest blow, you are mistaken. Nobody wins. We have all been devastated. We have all been trying to find some meaning in all of this suffering. Your damage was concrete; stripped of titles, degrees, enrollment. My damage was internal, unseen. I carry it with me. You took away my worth, my privacy, my energy, my time, my safety, my intimacy, my confidence, my own voice, until today. See one thing we have in common is that we were both unable to get up in the morning. I am no stranger to suffering. You made me a victim. In newspapers my name was "unconscious intoxicated woman," ten syllables, and nothing more than that. For a while, I believed that that was all I was. I had to force myself to relearn my real name, my identity. To relearn that this is not all that I am. That I am not just a drunk victim at a frat party found behind a dumpster, while you are the All American swimmer at a top university, innocent until proven guilty, with so much at stake. I am a human being who has been irreversibly hurt, my life was put on hold for over a year, waiting to figure out if I was worth something (Bever, 2016, p. 61).

\section{DISCUSSION}

\section{Summary of Parallels between Myths and Modern Cases}

It is interesting to realize that the only modern sexual assault survivor who was not vilified or devalued by the public and who enjoyed support from the media was the one who kept her identity private and never allowed her face and form to be publicized. This 'invisibility' might have protected Emily Doe from being 'mortalized' (knocked down from a 'virgin goddess' status) and kept her from being an easy target for either the media or the public. Brock Turner also was not officially a celebrity (or modern 'god'), even though there was testimony and media reports about his privileged status (i.e., Stanford University student and swimming star).

Rape myths, as well as Greek myths, provide simplistic narratives. It is human nature to prefer simplicity over complexity (Baker, 2016), and science itself requires parsimony in theory-making (Sober, 1981; Swinburne, 1997). The Greek myths contain viscerally potent images, or archetypes, that may become imbedded in the subconscious 
and allow patriarchal patterns to persist (Jung, 1969). This may occur through the process of heuristic reasoning (Chaiken and Trope, 1999; Kahneman, 2003; Stanovich, West, and Toplak, 2011), in which people come to conclusions based on unconsciously retained memory fragments rather than on conscious, reflective, systematic reasoning. The all-powerful male gods have been transformed in modern times to be our sports heroes or celebrities whose privilege protects them. The overly simplistic narratives of rape myths also provide support for the belief that the world is inherently fair (see just-world hypothesis, such as Lerner and Simmons, 1966; Rubin and Peplau, 1975); that bad things only happen for a victim-based reason; that, as long as a victim can be blamed, no one else needs to fear being violated.

"[T] he exercise of power, in modern society, is increasingly achieved through ideology, and more particularly through the ideological workings of language" (Fairclough, 2001, p. 3). By focusing on language, Fairclough (2001) believes it is possible to change embedded ideologies which create domination and oppression in modern society. Looking at language, which puts symbolism in words, helps to uncover powerful parallels between antiquity and today. In the Greek myth, when Medusa cast her gaze on people, they were turned to stone. In Desiree Washington's case, when she succeeded in getting Tyson convicted, the majority of the public became stone-cold and unsympathetic toward her. Medusa's beheading revealed the power of patriarchy to deny her existence as a whole person and have her exist only as a body. Desiree's personhood (or identity) was publicly erased by the media, which was evidenced by the Googling of her name not producing results separate and apart from the name of her rapist, whose world fame allowed him to attain (and retain) god-like status. Both Medusa and Desiree were doubly wronged by being violated and then by being seen as complicit in their own violations (Delong, 2012).

In Samantha Geimer's rape, the public's persistent unwillingness to censure Roman Polanski may be attributed to some remnant of sympathy toward him because of the horrific murder of his wife, Sharon Tate, and their unborn child (Bugliosi and Gentry, 2001). Polanski's own victimhood may have allowed him to be publicly viewed less like the predatory eagle from Greek mythology and more like the harmless swan. However, it was his stature as a Hollywood elite that enabled him to disguise his dark side to both Samantha Geimer and her mother and to exploit their innocence and gullibility. Some accounts of the Leda-Zeus encounter describe the rape as a seduction (GreekMythology.com); similarly, media accounts of Samantha Geimer's sexual assault minimized the violation, some reporting it as a consensual act despite the fact that Samantha Geimer was 13 years old while Polanski was 43. The legal system allowed Polanski to plead guilty to the lesser charge of Unlawful Sexual Intercourse with a Minor (Keegan, 2013), and the press persists even today in portraying Polanski's predation in a swanlike manner.

The sole sexual assault survivor in this analysis who retained her voice in a public forum was Emily Doe, a pseudonym which effectively hid her true identity. While it would be gratifying to believe that it is evolving standards of decency in a progressive society that engendered media and subsequent public support for her, it is just as likely that Emily Doe's hidden identity is what kept her from being the recipient of media scorn and victim blaming. Her invisibility made it difficult to be disparaging of her appearance, her demeanor, or her body language. Instead, she could only be judged by the facts of the case, making it easier for others to place themselves in her position (see Defensive Attribution Hypothesis; i.e., Cann et al., 1979; Kanekar and Vaz, 1983; Muller et al., 1994; Shaver, 1970; Thornton et al., 1982) and defer knee-jerk defensiveness for an attacker who was only a potential celebrity or sports star.

Besides being known as the god of wine, Dionysus is also known as the god of ecstasy. In modern society, we persist in using euphemisms and providing god status to a mythological male entity known for raping women after they were deliberately rendered unconscious from alcohol ingestion. One of the 'She asked for it' items in a typical rape myth acceptance scale is: If a woman is raped while she is drunk, she is at least somewhat responsible for letting things get out of control (Payne et al., 1999; McMahon and Farmer, 2011). Alcohol remains the drug of choice for would-be rapists to incapacitate their victims (Grubb and Turner, 2012). Despite this premeditated, predatory strategy on the part of rapists, more blame is often attributed to victims who have consumed alcohol prior to the attack (Richardson and Campbell, 1982; Scronce and Corcoran, 1991; Simms et al., 2007; Wild et al., 1998).

\section{CONCLUSION}

While this article's focus is male-on-female rape and examines gender roles, the researchers recognize the seriousness of male victims of sexual assault, same-gender victimization, and the changing ideation of gender in modern society. The primary purpose of this research was to determine if parallels existed between ancient myths and modern media-reported cases and, more importantly, to explore a Jungian explanation for those parallels. Patriarchy has been defined as a deliberate power control strategy, and such definition divides and polarizes the population. Our analysis makes it clear that, even though we may not have progressed past patriarchal patterns present in ancient myths, there may be an alternative reason, one not wholly hegemonically driven, for the persistence of these patterns. Powerful primordial forces may be influencing people on an unconscious level. We posit that these patriarchal patterns may persist because of archetypal images imbedded within a Jungian collective 
unconscious rather than because of consciously constructed patriarchal power. Our examination of archetypes as an alternative explanation for these persistent patriarchal patterns has not been offered to excuse wrong-doing, and it is not meant to minimize the harm caused. Instead, in the wake of emergent science across research fields (i.e., analytic psychology, behavioral psychology, evolutionary biology, and neuropsychology), Jung's theory of archetypes is now being recognized as relevant; and, as such, it has the potential to provide a practical way to root out ancient attitudes and create a safer society. The archetype explanation is offered as the means by which disparate disciplines, and even opposing ideological groups, might collaboratively come together to finally find solutions to a serious societal problem.

It was surprisingly easy to search out and select modern cases that paralleled mythological rapes. The three modern cases chosen were in our first group of four found by a simple Google search conducted on December 13, 2016: 'Celebrities convicted of rape.' We had to discard one case because we could not find an official disposition, and it appeared that the case may have been settled out of court. For the three cases selected, we found the parallels rather astounding, given the historical gap of thousands of years. We, as a society, need to be more fully cognizant of innate biases; we need to hold our heroes to a higher standard than the Greek gods; and we need to be much more mindful of the language being used by the media (and by ourselves) so as to alter behavioral patterns and progress past myths, both Greek-based and rape-based. Unless we become more reflective and less reactive, the light of reason may not uncover ancient stereotypes hidden deeply within the shadows.

\section{REFERENCES}

Baker, A, (2016). Simplicity. The Stanford Encyclopedia of Philosophy. Available at: https://plato.stanford.edu/archives/win2016/entries/simplicity/

Bever, L. (2016, June 4). 'You took away my worth': A sexual assault victim's powerful message to her Stanford attacker. The Washington Post. Available at: https://www.washingtonpost.com/news/earlylead/wp/2016/06/04/you-took-away-my-worth-a-rape-victim-delivers-powerful-message-to-a-formerstanford-swimmer/

Brown, J. M. and Hannigan, T. P. (2006). An empirical test of Carl Jung's collective unconscious (archetypal) memory. Journal of Border Educational Research, 5, 114-120.

Brownmiller, S. (1975). Against Our Will: Men, Women and Rape. New York: Fawcett Columbine.

Bugliosi, V. and Gentry, C. (2001). Helter Skelter: The True Story of the Manson Murders. New York: W. W. Norton \& Company.

Burgess-Jackson, K. (1996). Rape: A Philosophical Investigation. Aldershot: Dartmouth Publishing Company.

Burt, M. R. (1980). Cultural myths and supports for rape. Journal of Personality and Social Psychology, 38, 217-230. https://doi.org/10.1037/0022-3514.38.2.217

Cann, A., Calhoun, L. G. and Selby, J. W. (1979). Attributing responsibility to the victim of rape: Influence of information regarding past sexual experience. Human Relations, 32, 57-68. https://doi.org/10.1177/001872677903200104

Cartwright, M. (2012). Dionysos. Ancient History Encyclopedia. Available at: https:/ /www.ancient.eu/Dionysos/

Chaiken, S. and Trope, Y. (1999). Dual-process theories in social psychology. New York: Guilford Press.

Corliss, R. (2001, June 24). Law the bad and the beautiful. Time. Available at: http:/ / content.time.com/time/magazine/article/0,9171,159078,00.html

DeLong, A. (2012). Mesmerism, Medusa, and the Muse: The Romantic Discourse of Spontaneous Creativity. Lanham, MD: Lexington Books.

Doezema, M. (2018). France, where age of consent is up for debate: A case involving an 11-year-old girl has sparked a moment of moral and legal reckoning. The Atlantic. Available at: https://www.theatlantic.com/ international/archive/2018/03/frances-existential-crisis-over-sexual-harassment-laws/550700/

Dowden, K. (1995). Approaching women through myth: vital tool or self-delusion? in R. Hawley \& B Levick (Eds.), Women in Antiquity: New Assessments. Routledge: London, 1995, pp. 44-57.

Edwards, K. M., Turchik, J. A., Dardis, C. M., Reynolds, N. and Gidycz, C. A. (2011). Rape myths: History, individual and institutional-level presence, and implications for change. Sex Roles, 65(11-12), 761-773. https://doi.org/10.1007/s11199-011-9943-2

$\begin{array}{ccccccc}\begin{array}{l}\text { Encyclopaedia } \\ \text { https://www.britannica.com/topic/Tereus. }\end{array} & \text { Britannica. } & \text { (2018a). } & \text { Greek } & \text { Mythology. } & \text { Available at: } \\ \begin{array}{l}\text { Encyclopaedia } \\ \text { https://www.britannica.com/topic/Midas-Greek-mythology }\end{array} & \text { Greek } & \text { Mythology. } & \text { Available at: }\end{array}$

Fairclough, N. (2001). Language and power, 2nd Edition. Essex, England: Pearson Education Limited. 
Fitzpatrick, T., Playfoot, D., Wray, A. and Wright M. J. (2015). Establishing the reliability of word association data for investigating individual and group differences. Applied Linguistics, 36(1), 23-50. https://doi.org/10.1093/applin/amt020

Fonagy, P. (2003). Foreword: Freudian psychoanalysis and the natural sciences. In J. Knox, Archetype, Attachment, Analysis: Jungian Psychology and the Emergent Mind. New York: Brunner-Routledge.

Ford, T. E. and Ferguson, M. A. (2004). Social consequences of disparagement humor: A prejudiced norm theory. Personality and Social Psychology Review, 8, 79-94. https://doi.org/10.1207/S15327957PSPR0801_4

Freeman, P. (2013). Ob my gods: A modern retelling of Greek and Roman myths. Simon and Schuster.

Gelman, M. (1995, March 31). Shattered: We know all about Mike Tyson's release from prison - the limo, the mansion, the boxing prospects. But what about the woman he raped? Los Angeles Times. Available at: http://articles.latimes.com/1995-03-31/news/1s-49326_1_mike-tyson

Gibson, R. and Zillmann, D. (1994). Exaggerated versus representative exemplification in news reports: Perception of issues and personal consequences. Communication Research, 21, 603-624. https://doi.org/10.1177/009365094021005003

Goodwin, E. D. (2012). The neurobiology of the gods: How brain physiology shapes the recurrent images of myth and dreams. Routledge. https://doi.org/10.4324/9780203141526

GreekMythology.com (2018). Leda. Available at: https://www.greekmythology.com/Myths/Mortals/Leda/ leda.html

Grillner, S. (2006). Biological pattern generation: The cellular and computational logic of networks in motion. Neuron, 52, 5, 751-766. https://doi.org/10.1016/j.neuron.2006.11.008

Grinberg, E. and Shoichet, C. E. (2016, September 2). Brock Turner released from jail after serving 3 months for sexual assault. CNN. Available at: http://www.cnn.com/2016/09/02/us/brock-turner-release-jail/

Grubb, A. and Turner, E. (2012). Attribution of blame in rape cases: A review of the impact of rape myth acceptance, gender role conformity and substance use on victim blaming. Aggression and Violent Behavior, 17(5), 443-499. https://doi.org/10.1016/j.avb.2012.06.002

History of rape culture. (n.d.) Available at: http://historyofrapeculture.weebly.com/history-of-rape-culture.html

Huskinson, L. (2004). Nietzsche and Jung: The Whole Self in the Union of Opposites. New York: Brunner-Routledge. https://doi.org/10.4324/9780203508299

Huston, H. L., Rosen, D. H. and Smith, S. M. (1999). Evolutionary memory. In Rosen, D. H., \& Luebbert, M.C., (Eds.) Evolution of the Psyche. (pp. 140-149).

Iconis, R. (2008). Rape Myth Acceptance in College Students: A Literature Review. Contemporary Issues in Education Research, 1(2), 47-52. https://doi.org/10.19030/cier.v1i2.1201

James, M. (2018 Aug 8). Brock Turner, ex-Stanford University swimmer convicted of sexual assault, denied new trial. USA Today. Available at: https://www.usatoday.com/story/news/2018/08/08/stanford-universityswimmer-convicted-assault-denied-new-trial/943186002/

Judicial Language Project. (n.d.). New England Law, Boston. Available at: https://student.nesl.edu/centers/clsr_jlp.cfm

Jung, C. G. (1966). Collected Works of C. G. Jung. Volume 7: Two Essays on Analytical Psychology. New Jersey: Princeton University Press.

Jung, C. G. (1968). The importance of dreams. In C. G. Jung \&amp; M. L. von Franz (Eds.), Man and his symbols (pp. 3-94), USA: Dell Publishing.

Jung, C. G. (1969). The archetypes and the collective unconscious, $2^{\text {nd }}$ Edition. New Jersey: Princeton University Press.

Jung, C. G. (1972). Collected Works of C. G. Jung. Volume 8: The Structure and Dynamics of the Psyche. New Jersey: Princeton University Press.

Jung, C. (1978). Man and His Symbols. London: Picador (Pan Books).

Kahneman, D. (2003). Maps of bounded rationality: Psychology for behavioral economics. American Economic Review, 93, 1449-1475. https://doi.org/10.1257/000282803322655392

Kanekar, S. and Vaz, L. (1983). Determinants of perceived likelihood of rape and victim's fault. Journal of Social Psychology, 120, 147-148. https://doi.org/10.1080/00224545.1983.9712023

Keegan, R. (2013, Sept 16). Samantha Geimer tells her side of story in Roman Polanski case. Los Angeles Times. Available at: http://articles.latimes.com/2013/sep/16/entertainment/la-et-jc-geimer-book-20130916

Kolanko, M. and Cieply, M. (2015). Polish judge rejects extradition of Roman Polanski. The New York Times. Available at: https://www.nytimes.com/2015/10/31/world/europe/roman-polanski-polandextradiction.html

Kort-Butler, L. A. (2016). Content analysis in the study of crime, media, and popular culture. Oxford Research Encyclopedia of Criminology. Available at: http://criminology.oxfordre.com/view/10.1093/acrefore/ 9780190264079.001.0001/acrefore-9780190264079-e-23?print=pdf

Lerner, G. (1986). The creation of patriarchy. New York: Oxford University Press. 
Lerner, M. J., \& Simmons, C. H. (1966). Observer's reaction to the 'innocent victim:' Compassion or rejection? Journal of Personality and Social Psychology, 4, 203-210. https:// doi.org/10.1037/h0023562

Lightfoot, J. L. (2000). The bonds of Cypris: Nonnus' Aura. Greek, Roman, and Byzantine Studies, 39, 293-306.

Livingstone, C. (2008). Little Oxford English Dictionary \& Thesaurus. New York: Oxford University Press.

Lonsway, K. A. and Fitzgerald, L. F. (1994). Rape myths. In review. Psychology of Women Quarterly, 18(2), 133-164. https://doi.org/10.1111/j.1471-6402.1994.tb00448.x

Lule, J. (2001). Daily news, eternal stories: The mythological role of journalism. New York: Guilford Press.

MacLean, P. D. (1990). The triune brain in evolution: Role in paleocerebral functions. New York: Plenum Press.

McMahon, S. and Farmer, G. L. (2011). An updated measure for assessing subtle rape myths. Social Work Research, 35(2), 71-81. https://doi.org/10.1093/swr/35.2.71

Melas, C. and France, L. R. (2018). Bill Cosby, Roman Polanski expelled from the Academy. CNN. Available at: https://www.cnn.com/2018/05/03/entertainment/bill-cosby-roman-pollanski/index.html

Morgan, S. and Dennehy, R., (1 997). The power of organizational storytelling: a management development perspective. Journal of Management Development, 16(7). https://doi.org/10.1108/02621719710169585

Muller, R., Caldwell, R. and Hunter, J. (1994). Factors predicting the blaming of victims of physical child abuse or rape. Canadian Journal of Behavioral Science, 26, 259-279. https:// doi.org/10.1037/0008-400X.26.2.259

Murnen, S. K., Wright, C. and Kaluzny, G. (2002). If "boys will be boys," then girls will be victims?: A metaanalytic review of the research that relates masculine ideology to sexual aggression. Sex Roles, 46, 359-375. https://doi.org/10.1023/A:1020488928736

Nonnus, N.P. (2015). Book XLVIII. Delphi Complete Dionysiaca of Nonnus. Hastings: Delphi.

Nonnus, N. P. (1940). Dionysiaca; translated by Rouse, W H D, III Books XXXVI-XLVIII. Loeb Classical Library No. 346, Cambridge, Massachusetts, Harvard University Press; London, William Heinemann Ltd. Internet Archive

Norfolk, G. (2010). Greek Myths of Rape and Today. Available at: https:/ / falseallegations.wordpress.com/2010/12/22/8/

Oehling, J. and Cummins, A. (2017, April 4). Roman Polanski loses bid to resolve 40-year-old rape case. CNN. Available at: http://www.cnn.com/2017/04/04/us/roman-polanski-plea-rejected-court/

Payne, D. L., Lonsway, K. A. and Fitzgerald, L. F. (1999). Rape myth acceptance: Exploration of its structure and its measurement using the Illinois Rape Myth Acceptance Scale. Journal of Research in Personality, 33, 27-68. https://doi.org/10.1006/jrpe.1998.2238

Raphelson, S. (2017). Countries around the world move to repeal 'marry your rapist' laws. NPR. Available at: https:/ / www.npr.org/2017/08/09/542468265/countries-around-the-world-move-to-repeal-marry-yourrapist-laws

Richardson, D. and Campbell, J. L. (1982). The effect of alcohol on attributions of blame for rape. Personality and Social Psychology Bulletin, 8, 468-476. https://doi.org/10.1177/0146167282083013

Roesler, C. (2013). Evidence for the effectiveness of Jungian psychotherapy: A review of empirical studies. Behavioral Sciences, 3, 562-575. https://doi.org/10.3390/bs3040562

Rubin, Z. and Peplau, L. A. (1975). Who believes in a just world? Journal of Social Issues, 31, 65-89. https://doi.org/10.1111/j.1540-4560.1975.tb00997.x

Saldarriaga, N. (2015). Medusa: Sympathy for a Monster. September 22, 2015. Available at: https://classicalwisdom.com/medusa-sympathy-monster/

Sanday, P. R. (1981). The socio-cultural context of rape: A cross cultural study. Journal of Social Issues, 37, 5-27. https://doi.org/10.1111/j.1540-4560.1981.tb01068.x

Scronce, C. A. and Corcoran, K. J. (1991). Perceptions of date rape: Effects of outcome information and victims's alcohol consumption. In K. Corcoran, The influence of personality, cognition, and behavior on perceptions and metaperceptions following alcoholic beverage selection in a dating situation. Addictive Behaviors, 22(5), 577585. https://doi.org/10.1016/S0306-4603(96)00065-2

Serisier, T. (2017). Sex Crimes and the Media. Criminology and Criminal Justice: Oxford Research Encyclopedias. Available at: http://criminology.oxfordre.com/view/10.1093/acrefore/9780190264079.001.0001/ acrefore9780190264079-e-118

Shaver, K. (1970). Defensive attribution: Effects of severity and relevance of responsibility assigned for an accident. Journal of Personality and Social Psychology, 14, 101-113. https://doi.org/10.1037/h0028777

Shipp, E. R. (1992, March 26). Tyson gets 6-year prison term for rape conviction in Indiana. The New York Times. Available at: http://www.nytimes.com/1992/03/27/sports/tyson-gets-6-year-prison-term-for-rapeconviction-in-indiana.html?pagewanted $=$ all

Simms, C. M., Noel, N. E. and Maisto, S. A. (2007). Rape blame as a function of alcohol presence and resistant type. Addictive Behaviors, 32(12), 2766-2775. https://doi.org/10.1016/j.addbeh.2007.04.013 
Sober, E. (1981), The principle of parsimony. British Journal for the Philosophy of Science, 32, $145-56$. https://doi.org/10.1093/bjps/32.2.145

Sotirova-Kohli, M., Opwis, K., Roesler, C., Smith, S. M., Rosen, D. H., Vaid, J. and Djonov, V. (2013). Symbol/Meaning paired-associate recall: An "archetypal memory" advantage? Behavioral Sciences, 3(4), $541-561$. https://doi.org/10.3390/bs3040541

Spanoudakis, K. (2014). Nonnus of Panopolis in Context: Poetry and Cultural Milieu in Late Antiquity with a Section on Nonnus and the Modern World. Boston, MA: Walter de Gruyler GmbH \& Co. https:// doi.org/10.1515/9783110339420

Stanovich, K. E., West, R. F. and Toplak, M. E. (2011). Individual differences as essential components of heuristics and biases research. In J. S. B. T. Evans, K. I. Manktelow, D. E. Over and S. Elqayam (Eds.), The Science of Reason: A Festschrift for Jonathan St. B.T Evans (pp. 355-396). New York, NY: Psychology Press.

Stevens, A. (1994). Jung: A Very Short Introduction. Oxford University Press.

Suarez, E. and Gadalla, T. M. (2010). Stop blaming the victim: A meta-analysis on rape myths. Journal of Interpersonal Violence, 25(11), 2010-2035. https:/ / doi.org/10.1177/0886260509354503

Swinburne, R., (1997), Simplicity as Evidence for Truth, Milwaukee, WI: Marquette University Press.

Thornton, B., Ryckman, R. and Robbins, M. (1982). The relationship of observer characteristics to beliefs in causal responsibility of victims of sexual assault. Human Relations, 35, 321-330. https://doi.org/10.1177/001872678203500404

Toobin, J. (2009, December 14). The celebrity defense: Sex, fame, and the case of Roman Polanski. The New Yorker. Available at: http://www.newyorker.com/magazine/2009/12/14/the-celebrity-defense

Walters, B., narrator/interviewer. (1992). Interview of Desiree Washington. 20/20. ABC News. Available at: https://www.youtube.com/watch?v=IIyzSi84V-U

Whisnant, R. (2007). Thinking about National and Bodily Sovereignty. Global Feminist Ethics, 155-176.

Wild, T. C., Graham, K. and Rehm, J. (1998). Blame and punishment for intoxicated aggression: When is the perpetrator culpable? Addiction, 93(5), 677-687. https://doi.org/10.1046/j.1360-0443.1998.9356774.x

Wilkerson, D. (2019). Friedrich Nietzsche (1844-1900). The Internet Encyclopedia of Philosophy. Available at: https://www.iep.utm.edu/nietzsch/

Yeats, W. B. (1928). The Tower. (A Facsimile Edition). Simon \& Schuster. Available at: http://www.simonandschuster.com/books/The-Tower/William-ButlerYeats/9780743247283/browse_inside

Zeitlin, F. I. (1995). Signifying difference: the myth of Pandora. In R. Hawley and B. Levick (Eds.), Women in Antiquity: New Assessments. Routledge: London, pp. 58-74. 